\title{
Mechanical and Thermal Properties of Polylactic Acid with Cellulose Nanofiber Modified by Cardo Material (BPFG) or Bisphenol-A Diglycidyl Ether (BPAG) (II)
}

\author{
Shinya KATSURADA", Hirokazu SATO*, Katsuhisa TOKUMITSU*, \\ Masahiro YAMADA $^{* *}$ and Masayuki SUGIMOTO** \\ " Department of material science, Graduate school of engineering, University of Shiga Prefecture \\ 2500 Hassaka-cho, Hikone Shiga 522-8533, Japan \\ ** Osaka Gas Co., Ltd. \\ 6-19-9 Torishima Konohana-ku Osaka 554-0051 Japan
}

\begin{abstract}
In our previous paper, we reported that the cellulose nano-fiber (CNF) treated with Cardo material (BPFG), referred to as B-CNF, dispersed finely in an organic solvent as well as in polylactic acid (PLA) matrix, and the mechanical properties (especially at the temperature region above the grass transition temperature, Tg) of PLA/CNF composites were improved with the amount of B-CNF content $(0.3,0.5$, and $1.1 \mathrm{wt} \%)$ in the composites. However, the degree of substitution of BPFG on CNF was only $8.6 \mathrm{wt} \%$ (18.6 mmol\%) and the effect of the substitution of BPFG was not determined.

In this study, we prepared several B-CNF with various degrees of substitution to BPFG and examined the effect of the substitution on the mechanical properties of PLA/B-CNF composites. Moreover, we also prepared the CNF treated by Bisphenol-A diglycidyl ether (BPAG), which does not have Cardo structure in its chemical structure, and determined the effect of the difference in chemical structure (with/without Cardo structure) on their mechanical properties at high temperature.

Master batches were prepared by mixing CNF and PLA in an organic solvent and then they were further blended with PLA in a kneader at $150{ }^{\circ} \mathrm{C}$. TEM observation revealed that both of the CNF treated with BPFG (B-CNF) and that treated with BPAG (BisA-CNF) dispersed homogeneously in the PLA. The storage moduli of B-CNF/PLA composites above Tg increased with the degree of BPFG substitution. The storage moduli of B-CNF/PLA and BisA-CNF/PLA with similar degree of substitution were about 5 times higher than that of neat PLA above Tg, and the modulus of B-CNF/ PLA was slightly higher than that of BisA-CNF/PLA. Moreover, the peak intensity of tan $\delta$ of B-CNF/PLA and BisACNF/PLA were lower than that of neat PLA, and the intensity of $\tan \delta$ of B-CNF/PLA was lower than that of BisA$\mathrm{CNF} / \mathrm{PLA}$. These results suggest that the molecular motion of PLA was restricted by the presence of B-CNF and BisACNF because the interaction between PLA and B-CNF or BisA-CNF is much stronger than that in untreated CNF/PLA. Furthermore, B-CNF improved the mechanical properties of the composite more effectively than BisA-CNF for the PLA composite above Tg. From the result of Coefficient of Thermal Expansion (CTE) measurements, we estimated the volume fraction of PLA phase interacting with B-CNF and BisA-CNF by means of the "mixtures rule". As a result, it was found that the PLA phase interacting with of B-CNF/PLA is larger than that in BisA-CNF/PLA. This may be one of the factor which caused the difference in their mechanical properties of B-CNF/PLA and BisA-CNF/PLA. Finally, CTE measurements revealed that there is a strong relation between the intensity of $\tan \delta$ at $\mathrm{Tg}$ and the volume fraction of the PLA interacting phase in PLA matrix.
\end{abstract}

Key Words: Cellulose nanofiber / Composite / Poly(lactic acid) / Bisphenol fluorene diglycidyl ether (BPFG) /

Bisphenol-A diglycidyl ether (BPAG)

\section{カルド修飾 CNF/PLA コンポジット材料のカ学的・熱的物性評価研究 (II) \\ 桂田 慎也 ${ }^{*}$, 佐藤 嘉計 ${ }^{*}$, 徳満 勝久 *, 山田 昌宏 ${ }^{* *}$, 杉本 雅行 ${ }^{* *}$}

\footnotetext{
* 滋賀県立大学大学院 工学研究科 材料科学専攻

于 522-8533 滋賀県彦根市八坂町 2500

$\dagger$ Tel: 0749-28-8370, E-mail: ktokumit@mat.usp.ac.jp

**大阪ガス株式会社

于 554-0051 大阪府大阪市此花区酉島 6-19-9
} 


\section{1. 緒言}

現代社会において, 右肩上がりの経済状態を維持するた めには, エネルギーの大量消費と一般消費財の大量生産が重 要となり, そのため資源の枯渇問題や, 大量に発生するゴ ミの処分問題, さらには地球温暖化を始めとする環境問題 が世界的規模の課題として挙げられている。 そこで，ポリ 乳酸 (以下: PLA) 等の植物由来のバイオプラスチック材料 が, 温室効果ガスの一つである $\mathrm{CO}_{2}$ の固定化を可能する「カー ボンニュートラル」な材料として注目を集めている。また, PLA は生分解性ポリマーでもあり, 食料品用パック等に用 いられているが PLAのガラス転移温度 $\left(\mathrm{T}_{\mathrm{g}}\right)$ が $60{ }^{\circ} \mathrm{C}$ 近傍に 存在し, 比較的低温でも軟化が生じることから耐熱性の向 上が大きな課題となっている。 そのため, PLA を Tg 以上の 高温領域で使用する際には結晶化度を高めて使用する必要 がある. しかしながら, PLA は熱可塑性樹脂の中でも結晶化 速度は遅く, 通常の成形加工プロセスにおいては高い結晶 化度を得ることは困難な状況である。 そこで, PLA 中に結 晶化促進剂や可塑剂を添加し, 結晶化を促進させるという 方法が用いられている. ${ }^{1-3)}$ また, PLLAと PDLAの等量混合 物することにより, 融点の高いステレオコンプレックス (SC) を生成させる方法や, 高分岐構造を有するポリマーとの複 合化，無機フィラーや繊維材料をPLA に添加することによ り，高温における力学特性の向上効果を報告している.-6)

一方，セルロースナノファイバー（以下：CNF）は, 植物 の細胞壁にフィブリル状態で存在するセルロースを，ナノレ ベルまで解繊処理を施すことによって得られる植物由来の 材料である. そのため, 地球上に存在する全ての植物原料 （蓄積量は 1 兆卜ン以上）から CNF を調製することが可能 であり，実際に稲や豆款 ${ }^{7)}$, 麦わら ${ }^{8)}$, ジャガイモ ${ }^{9)}$, バガ 又 ${ }^{10)}$, バナナの花軸や偽茎 ${ }^{11}$, 大麻や亜麻の鞁皮繊維 ${ }^{12)}$ どから CNF が調製されている. Nishinoらは, セルロースミ クロフィブリル中に存在する結晶領域のヤング率は $138 \mathrm{GPa}$ と報告しており ${ }^{13)}$, Helbert らはその引張り強度は $10 \mathrm{GPa} に$ も達すると予想している. ${ }^{14)}$ しかしながら, 一般的なパプル 纎維の強度はそれ程大きな值ではないため, CNF 中の Semicrystalline の強度は $2 \mathrm{GPa}$ 程度と見積もられている. ${ }^{15)}$ しか し, この值は軟鋼の強度の約 5 倍に相当し, また CNF の密 度は $1.59 \mathrm{~g} / \mathrm{cm}^{3}$ と軟鋼の $1 / 5$ 程度 ${ }^{16)}$ と, ポリイミド繊維と同 等の特性を有しながら生分解をも有する軽くて強い天然繊 維状材料の一つである. さらに, CNF は石英と同程度の小 さな線熱膨張係数 $(0.17 \mathrm{ppm} / \mathrm{K})$ を有することから, 温度変化 にともなう “膨張・収縮”の少ない複合材料用補強纎維と

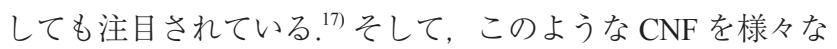
プラスチックと複合化することにより各種物性を向上させ るという研究結果が数多く報告されている. ${ }^{18-20)}$ 岩竹らは非 晶性の PLA に CNF を $10 \mathrm{wt} \%$ 添加することにより, ガラス 転移温度 $\left(\mathrm{T}_{\mathrm{g}}\right)$ 以上での貯蔵弾性率 $\left(E^{\prime}\right)$ が劇的に向上したこ

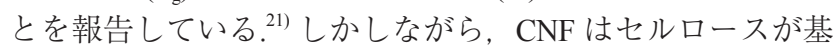
本構造であり分子内に多数の親水基（-OH 基）を有するた め, 疎水性的性質を有する汎用ポリマー中において分散す

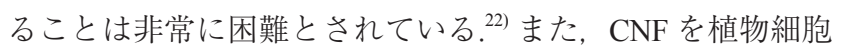
壁から単離するには機械的解纎処理を数十回程度実施され るのが通常であるが, CNF の力学物性の低下を抑制するに は機械的解繊処理はできる限り簡便かつ最小のエネルギー
で行う必要がある. ${ }^{23}$ そこで, 機械的解繊処理を効果的に行 うための前処理法として，セルロース分子内の C6 位の炭素 を選択的に酸化し静電的な反発力で解繊処理を容易にする 2,2,6,6-tetramethylpiperridine-1-oxyl (TEMPO) 酸化法 ${ }^{24)} や$, そ の他, カチオン化法 ${ }^{25)}$, 酵素処理法 ${ }^{26)}$ などが検討されている.

一方，フルオレン骨格を分子内に有するカルド材料は, 非常に嵩高い構造を有しており，近年カーボンナノチュー ブなどのナノ材料に対して高い分散性を発現する効果など が報告されている. ${ }^{27)}$ また，当研究室ではカルド材料が PLA と相互作用を有し，PLAの結晶化速度やモルフォロジーに

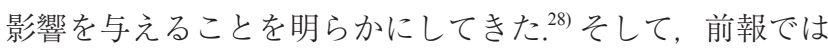
エポキシ基を 2 個有する反応性カルド材料 (BPFG) を用いて CNF を表面改質した B-CNF をPLA と複合化することによ り, (1)ガラス転移温度 (Tg) 以上での弾性率の向上効果, (2) 温度 $90{ }^{\circ} \mathrm{C}$ での力学物性の向上効果, (3)温度 $105{ }^{\circ} \mathrm{C}$ での高 ひずみ状態までの弾性率の維持効果, (4) $\mathrm{Tg}$ 以上での熱膨張 係数の低減化効果等について報告を行った ${ }^{29)}$ しかしながら, その際に用いた B-CNF は CNFへのBPFGの反応置換量が $18.6 \mathrm{mmol} \%$ の試料のみであり, BPFG 添加量に対する PLA の改質効果に関する検討は未実施であった。 また，BPFG中 に存在するカルド構造（フルオレン骨格）の影響に関して, 「ビスフェノール A 型構造」との違いついても検討されてお らず, “カルド構造の優位性”に関する知見についても不明 であった。そこで本研究では, BPFG 添加量の異なる CNF 材料を調製した後にPLA との複合化を行い, PLAの物性改 質に与える影響について検討を行うとともに, カルド構造を 分子構造中に有しない Bisphenol-A diglycidyl ether (BPAG) を 用いて CNF を処理したBisA-CNF を用いた系との比較を行 うことにより, カルド構造の優位性について検討を行った.

\section{2. 実験}

\section{1 試料}

マトリクスとなるポリ乳酸 (PLA) には非晶性の PDLLA $\left(\mathrm{Mw}=2.7 \times 10^{5} \mathrm{~g} / \mathrm{mol}, \mathrm{Mn}=1.7 \times 10^{5} \mathrm{~g} / \mathrm{mol}, \mathrm{D}\right.$ 体含有率: $12 \mathrm{~mol} \%$, ガラス転移温度 $\left(\mathrm{T}_{\mathrm{g}}\right): 62{ }^{\circ} \mathrm{C}$, 三井化学（株）社製 LACEA H-280) を用いた。 セルロースナノファイバー (CNF)に は，セリッシュ KY-110N（(株）ダイセル社製）を用いた。 カルド構造を有する材料としては, Fig. 1 に示すような構 造を持つビスフェノールフルオレンジグリシジルエーテ ル (Bisphenol fluorene diglycidyl ether: BPFG)（大阪ガスケミ カル(株製）とフルオレン骨格（カルド構造）を有しないビ スフェノール A グリシジルエーテル (Bisphenol-A diglycidyl ether:BPAG)（三菱化学(株)製 JER828）を用いた。このBPFG と BPAGを用いて, CNF を混合した有機溶媒中（ジオキサ ンなど）で，4級アンモニウム塩触媒とともに温度 $120^{\circ} \mathrm{C}$ で 2 時間程度, アルゴン雲囲気中で反応させることにより BPFG 修飾した CNF（以下，B-CNF と略す）と BPAG 修飾 CNF（以下 BisA-CNF）を調製した。 反応置換割合は，以下 の手順で洗浄・精製した B-CNF およびBisA-CNFを用いて, FT-IR 測定（サーモフィッシャーサイエンティフィック社製 Nicolet iS5, 測定波数 $600 \sim 4000 \mathrm{~cm}^{-1}$, 積算回数 64 回）に より決定した。まず，B-CNF および BisA-CNF(0.1 g) にジオ キサン $50 \mathrm{~g}$ を加えた後, 超音波で 60 分間処理した。その 後, 遠心分離（1200 rpm，30 分）を 3 回実施し，上澄みを 
除去した. 次に, 検量線は未置換 CNF のセリッシュに既定 量のフルオレンを混合した試料を標準サンプルとし, 芳香 族環 $\left(1506 \mathrm{~cm}^{-1}\right)$ とセルロースの環内 $\mathrm{CH}\left(1370 \mathrm{~cm}^{-1}\right)$ の吸収バ ンドとの比より算出した. その結果, $\mathrm{CNF}$ を $\mathrm{BPFG}$ で処理 することによるセルロース構造中の - $\mathrm{OH}$ 基と $\mathrm{BPFG}$ との反 応置換割合は $18.4 \mathrm{mmol} \%, 28.5 \mathrm{mmol} \%, 38.5 \mathrm{mmol} \%$ であり, $\mathrm{BPAG}$ で処理した CNF の反応置換割合は $38.7 \mathrm{mmol} \%$ であっ た.

\section{2 複合材料調製条件}

各種 CNF と PLA との複合材料調製には, 先行研究の結果 より良好な力学物性が得られたマスターバッチ法を用いた。 マスターバッチ $(\mathrm{MB})$ の調製条件は, アセトン $600 \mathrm{~mL}$ 中に 各種 CNF(1.25 g) を分散し, 温度 $60{ }^{\circ} \mathrm{C}$ で PLA $50 \mathrm{~g}$ と混合し, 超音波振とう機中で 48 時間溶解混合後, 溶媒を除去する方 法で行い, CNF の含有率が $2.2 \mathrm{wt} \%$ の PLA 複合化 MB を調 製した。 そして, 二軸式ローター混練機（東洋精機製作所 社製 LABOPLASTMILL 50M）を用いて温風乾燥機中 $40{ }^{\circ} \mathrm{C}$ で 24 時間真空乾燥したPLA と混練温度 $150{ }^{\circ} \mathrm{C}$, 回転速度 $20 \mathrm{rpm}$ で 2 分間混練を行った後, さらに $40 \mathrm{rpm}$ で 10 分間 混練を行うことにより各種 CNF と PLA との複合材料を調製 した。 なお，本実験での PLA と各種 CNFの含有割合は全て $1.1 \mathrm{wt} \%$ となるように, MB P PLA で薄めることにより各種 PLA 複合化サンプルの調製を行った。作製した各複合化サ ンプルのサンプルコードを Table I に示した. 作製した各サ ンプルをペレット状に加工した後, 温度 $155^{\circ} \mathrm{C}$, 圧力 $10 \mathrm{MPa}$ にてホットプレスを行い, 水水中にてクエンチすることによ り, 厚さ $100 \mathrm{~mm} \times 100 \mathrm{~mm} \times 0.3 \mathrm{~mm}$ のフィルムを調製した

(a) BPFG

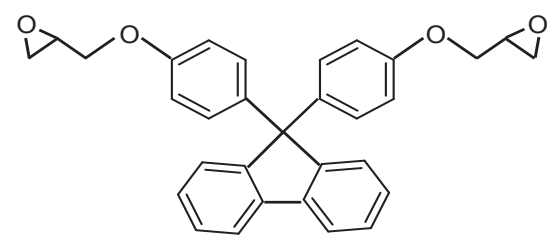

(b) BPAG

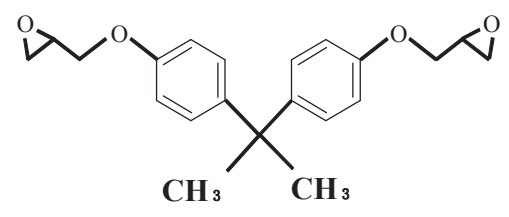

Fig. 1. Chemical structure of (a) BPFG and (b) BPAG.

Table I. Sample code.

\begin{tabular}{ccccc}
\hline Modifier & \multicolumn{5}{c}{ BPFG } & BPAG \\
\hline $\begin{array}{c}\text { Content } \\
(\mathrm{mmol} \%)\end{array}$ & 18.4 & 28.5 & 38.5 & 38.7 \\
\hline Sample Code & $\begin{array}{c}\text { B-CNF } \\
(18.4) / \mathrm{CNF}\end{array}$ & $\begin{array}{c}\text { B-CNF } \\
(28.5) / \mathrm{CNF}\end{array}$ & $\begin{array}{c}\text { B-CNF } \\
(38.5) / \mathrm{CNF}\end{array}$ & $\begin{array}{c}\text { BisA-CNF } \\
(38.7) / \mathrm{CNF}\end{array}$ \\
\hline
\end{tabular}

\section{3 実験}

各 PLA 複合材料中における各種 CNF の分散性に関して, 四酸化ルテニウム処理を行った後, TEM 観察 (JEOL（株） 社製 $\mathrm{ARM} 200 \mathrm{~F}$ ，加速電圧 $(\mathrm{HV}) ： 100 \mathrm{kV})$ により評価した. PLA の分子運動性の評価には（株）UBM 製 Rheogel-E4000 を用いて動的粘弾性測定 (DMA) を行い, 貯蔵弾性率 $\left(E^{\prime}\right)$

および $\tan \delta$ の温度分散を評価した。測定温度範囲は $30 \sim$ $110^{\circ} \mathrm{C}$, 周波数は $1 \mathrm{~Hz}$, 昇温速度は $1.5^{\circ} \mathrm{C} / \mathrm{min}$ で行った。高 温における静的引張り試験は同装置を用い, 恒温槽内温度 $90{ }^{\circ} \mathrm{C}$, 引張速度は $0.0175 \mathrm{~mm} / \mathrm{sec} て ゙$ 行った。 また, 貯蔵弾 性率の歪み依存性測定は温度 $105{ }^{\circ} \mathrm{C}$, 周波数 $30 \mathrm{~Hz}$ の条件で 行った，各複合材料の線熱膨張係数 (CTE) は, （株）リガク 製 Thermo Plus TMA 8310 を用い, 温度範囲 $30 \sim 110{ }^{\circ} \mathrm{C}$, 荷重 $49 \mathrm{mN}$ の引張モードの条件で測定を行った。

上記 DMA 測定より得られたPLAの貯蔵弾性率 $\left(E^{\prime}\right)$ およ びCTEの結果を元に, 各複合材料における CTEの温度依存 性データとのカーブフィッティングを Fig.2 に示した複合モ デルを用いて行い，(1) 式を用いて A 相，B相および A' 相 の体積分率を算出した ${ }^{30)}$ なお，マトリクス相であるPLAの 独立成分を $\mathrm{A}$ 相, 分散相である各種 CNF 成分を B 相, B 相 と相互作用していると考えられるPLA成分を A'相と仮定し, 分散相と相互作用を有する PLA 成分 (A'成分) の体積分率 を見積もることにより，複合材料中での CNF，B-CNF あるい は BisA-CNF がPLA マトリクスに与える影響について検討し た。なお，測定を行った温度範囲における各種 CNF の CTE および弾性率の值は, 測定温度範囲内 $\left(110^{\circ} \mathrm{C}\right.$ 以下) におい て殆ど変化せずほぼ一定と仮定し, それぞれ $\alpha_{\mathrm{B}}=0.17 \mathrm{ppm} / \mathrm{K}$, $E_{\mathrm{B}}=138 \mathrm{GPa}$ とした. ${ }^{13,17)}$

$$
\alpha_{c}=(1-\phi) \alpha_{A}+\phi \frac{\alpha_{A}(1-\lambda) E_{A}+\alpha_{B} \lambda E_{B}}{(1-\lambda) E_{A}+\lambda E_{B}}
$$

\section{3. 結果と考察}

Fig.3には, MB を作成する際にアセトン $600 \mathrm{~mL}$ 中に B-CNF と BisA-CNFを $1.25 \mathrm{~g}$ 分散した時の写真を示した。攪 拌中は溶液中で一様に分散している両系であったが（図中 (a)），攪拌停止後 5 分が経過すると BisA-CNF は次第に凝集

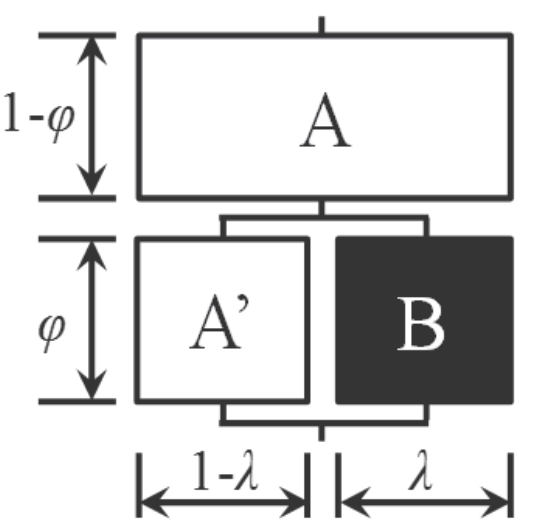

Fig. 2. Schematic complex model of mixture rule. 
し沈殿したが，B-CNFでは凝集や沈殿などの目視できる現 象は確認されなかった。この結果より, B-CNF はアセトン などの有機溶媒中でも安定に分散した状態で存在すること が分かった。

Fig. 4 に各 B-CNF，BisA-CNF を $1.1 \mathrm{wt} \%$ 添加した PLA 複 合材料の TEM 像を示す。前報において未処理の CNF を添 加したCNF/PLA 中での CNF の分散性は不良であったのに 対して, BPFGで処理した CNF(B-CNF) をPLA に添加した系 では，PLA 中で非常に微細かつ均一なサイズの CNF として 存在することが分かった ${ }^{29)}$ しかしながら，その分散状態が BPFG の反応置換割合に影響されるような傾向は認められな かった。一方, BisA-CNFを PLA に添加した複合材料の分散 状態は B-CNF と大差なく, PLA 中において B-CNF と同程度 の分散性を有することが分かった。 これらの結果より，以 下に述べる B-CNF と BisA-CNFを添加したPLA 複合材料の 物性改質効果では,それぞれの“分散状態の違い”ではなく, CNF の“表面状態の違い” よる効果について比較検討でき (a)

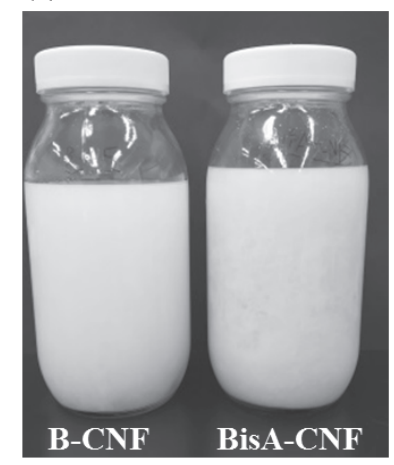

(b)

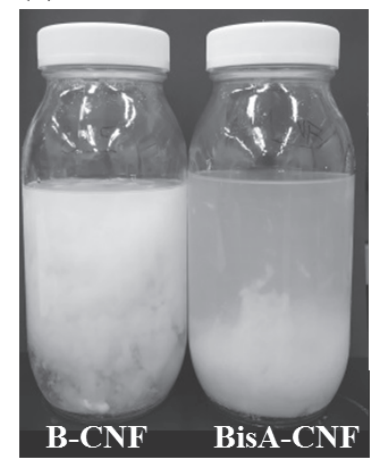

Fig. 3. Picture of B-CNF and BisA-CNF in organic solvent: (acetone): (a) just after stop stirring and (b) after stop stirring for $5 \mathrm{~min}$.

\section{るものと考えられる.}

Fig. 5 に未処理の CNF と BPFG との反応置換割合の異なる B-CNF をPLA に $1.1 \mathrm{wt} \%$ 添加したサンプルの DMA 測定結 果 ((a) 貯蔵弾性率, (b) $\tan \delta)$ を示す。図中 (a)において, い ずれの PLA 複合材料系においても CNF あるいは B-CNF を 添加することにより， $\mathrm{T}_{\mathrm{g}}$ 以上の温度領域で未添加 PLA より E'が増加することが分かった。 また，その増加割合は，未 処理の CNF と B-CNF(18.4)ではほとんど同じであったが, BPFG の反応置換割合の増加に伴い $\mathrm{T}_{\mathrm{g}}$ 以上の温度領域にお ける $E^{\prime}$ が顕著に増加する結果となった。これは, 微細に分 散した B-CNF が PLA マトリクスを顕著に補強する効果を示 す結果であり，これはB-CNF と PLA マトリクス界面におけ る相互作用が BPFGの置換割合の増加と共に向上したことを 示唆する結果であると考えられる. 特に, PLAの Tg 以上の 温度範囲における $E^{\prime}$ のプラトー領域における B-CNF(38.5)/ PLA の $E^{\prime}$ は約 $12 \mathrm{MPa}$ と最も高い值を有しており，それは neat PLA の值（約 $2 \mathrm{MPa}$ ）の約 6 倍に相当する結果であった.

(1) Storage modulus

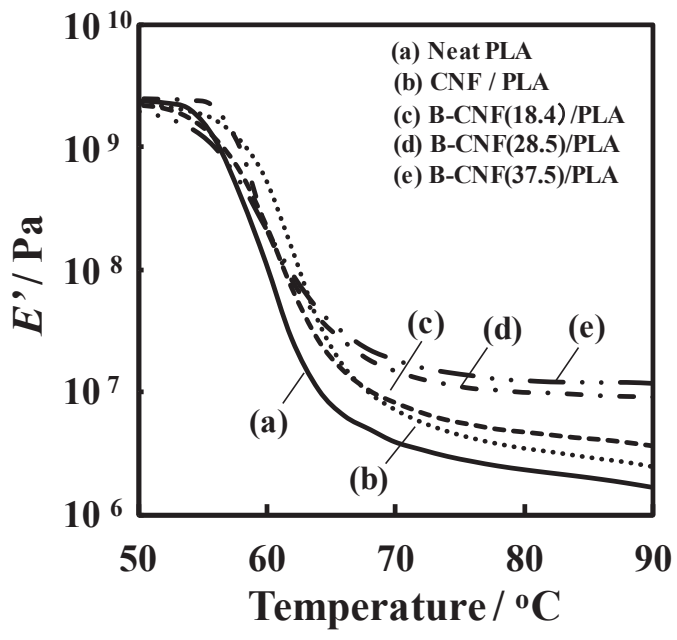

(2) $\tan \delta$

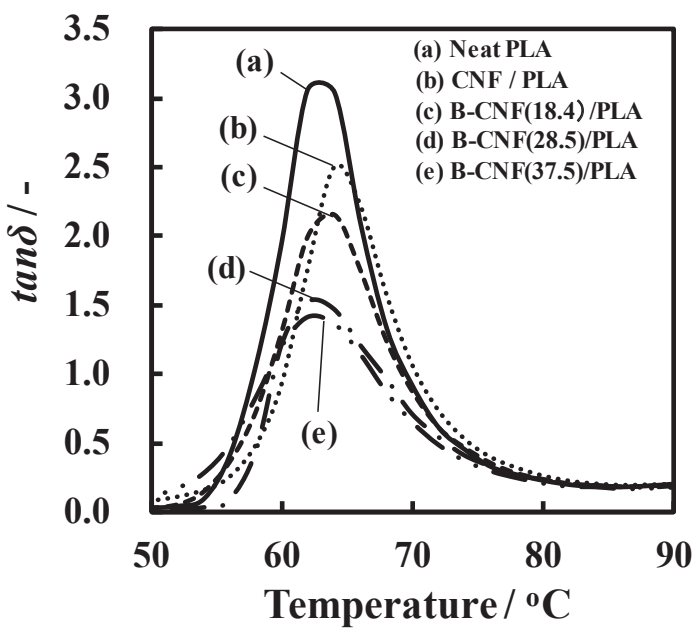

Fig. 5. DMA results of neat PLA and several CNF composites (CNF content $1.1 \mathrm{wt} \%$ ) : (1) Storage modulus and (2) $\tan \delta$ : (a) Neat PLA, (b) CNF/PLA, (c) B-CNF(18.4)/PLA, (d) B-CNF(28.5)/ PLA, and (e) B-CNF(38.5)/PLA. 
次に, 同図中 (b) の $\tan \delta$ の変化より, 未処理の $\mathrm{CNF}$ と $\mathrm{BPFG}$ との反応置換割合の異なる B-CNF を添加した PLA 複合材料 を比較すると, BPFGの置換割合の増加とともに $\tan \delta$ のピー ク強度が減少した。 これは, PLA との界面近傍に存在する CNF 或いはB-CNF がPLAの分子運動を抑制したためと考え られ, 特にBPFGの置換割合の高い B-CNF(38.5)/PLA の系で はその効果は顕著であり, B-CNF は PLA 分子の運動性を著 しく抑制する効果を発現するものと考えられる.

Fig.6には, 未処理の CNF/PLA と反応置換割合がほぼ同じ B-CNF(38.5)/PLA と BisA-CNF(38.7)/PLA の DMA 測定結果を 示した。図中 (a) 貯蔵弾性率の測定結果において, Tg 以上 の高温領域では未処理の CNF より BisA-CNF(38.7)/PLA の $E^{\prime}$ が増加するものの, その值は B-CNF(38.5)/PLAよりもいずれ も低いことが分かった。一方, 眓中 (b) $\tan \delta$ の測定結果にお いては, 未処理の CNF を添加したPLA より BisA-CNF(38.7)/ PLAの $\tan \delta$ のピーク強度が減少するものの, B-CNF(38.5)/ PLA が最も小さな $\tan \delta$ のピーク強度を有することが分かっ

(1) Storage modulus

(a) $\mathrm{E}$,

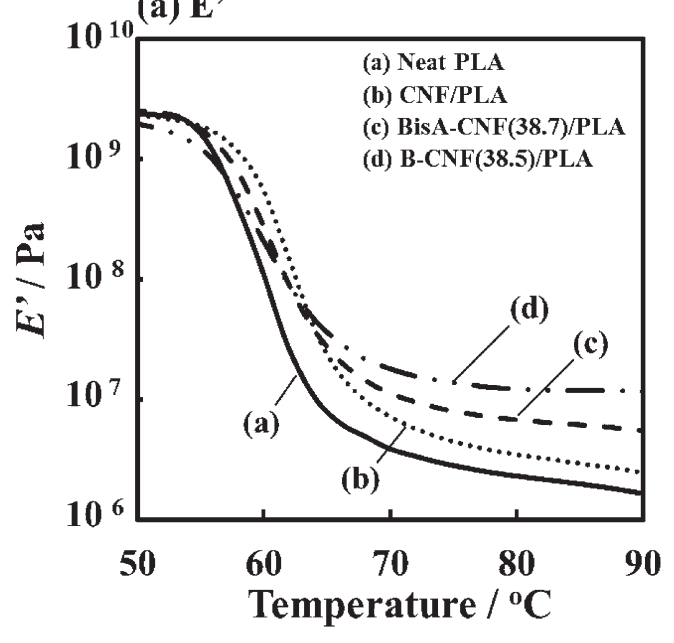

(2) $\tan \delta$

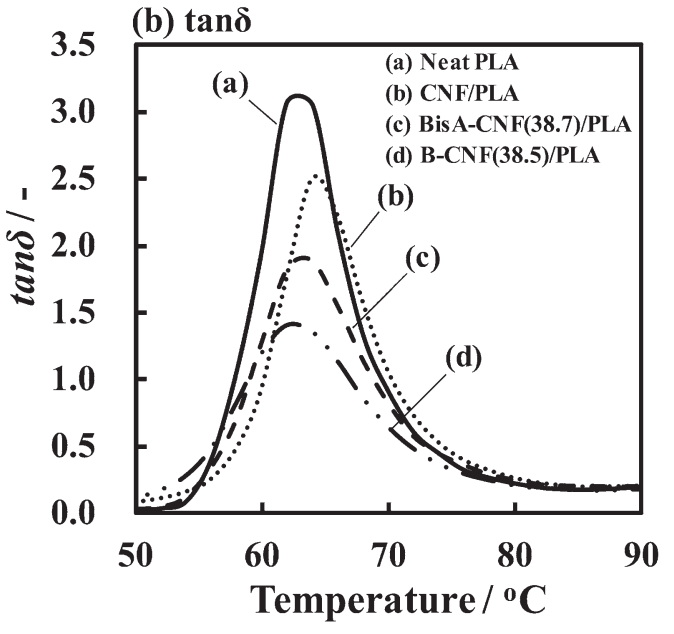

Fig. 6. DMA results of (1) Storage modulus and (2) $\tan \delta$ for neat PLA and several CNF composites (CNF content $1.1 \mathrm{wt} \%$ ) : (a) Neat PLA, (b) CNF/PLA, (c) BisA-CNF(38.7)/PLA, and (d) B-CNF(38.5)/PLA.
た.これらの結果から, カルド構造を有する $\mathrm{BPFG} て ゙$ 処理し た CNF(B-CNF) が, カルド構造を有しないビスフェノール A 型構造の BPAG で処理した CNF(BisA-CNF) より PLA との複 合化による物性改質効果が顕著であり, それはカルド構造 に起因する特性によるものと推察される。しかしながら,「な ぜカルド構造がそのような特性を有するのか？」について は, カルド構造という剛直で自由体積空間が広いという特 徵が一要因としてあげられるものの, 不明な点も多く今後 さらなる検討が必要と考えられる。

Fig. 7 に各 CNF と PLA 複合材料の $\mathrm{Tg}$ 以上の温度域 $\left(80^{\circ} \mathrm{C}\right.$, $\left.90{ }^{\circ} \mathrm{C}\right)$ における静的引張り試験の結果を示した。 図中 (a)に

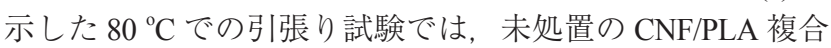
材料の力学物性 (弾性率, 強度) が最も低く, B-CNF/PLA では BPFGの反応置換割合の増加とともに弾性率, 強度と もに顕著に増加することが分かった。一方, BisA-CNF(38.7)/ PLA では, 未処理の CNF/PLA 複合材料より力学物性は向上 するものの, 反応置換割合が同じB-CNF(38.5)/PLA ほど力 学物性の改善効果は顕著ではなく, B-CNF(18.4)/PLA とほぼ

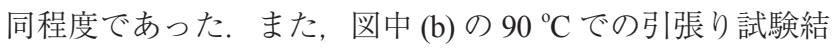

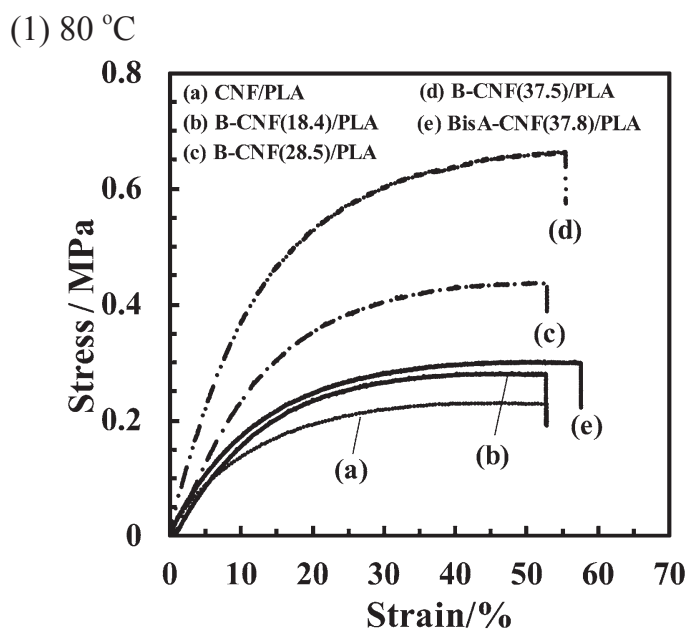

(2) $90{ }^{\circ} \mathrm{C}$

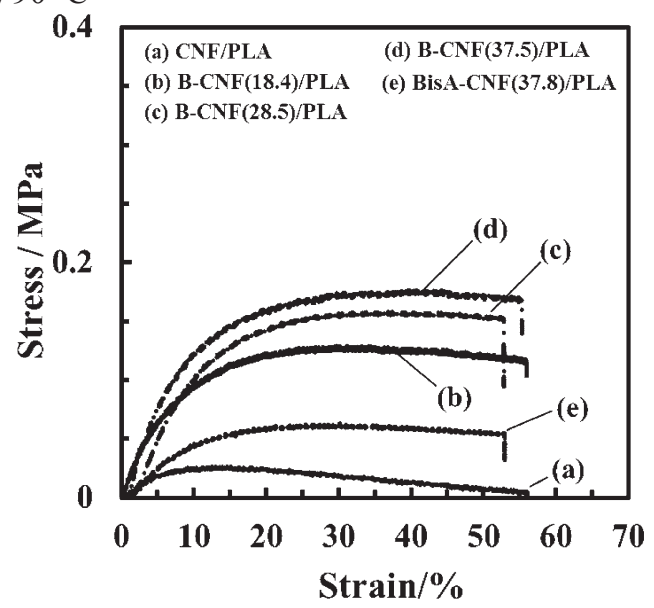

Fig. 7. Stress-strain curves at (1) $80{ }^{\circ} \mathrm{C}$ and (2) $90{ }^{\circ} \mathrm{C}$ for several CNF/ PLA composites (CNF content $1.1 \mathrm{wt} \%$ ): (a) CNF/PLA, (b) B-CNF(18.4)/PLA, (c) B-CNF(28.5)/PLA, and (d) B-CNF(38.5)/ PLA, and (e) BisA-CNF(38.7)/PLA. 
果では, 各種複合材料の力学物性の差は小さくなるものの, 依然として B-CNF/PLA 系複合材料ではBPFGの反応置換 割合の増加に依存して力学物性が向上する傾向が認められ た。また, BisA-CNF(38.7)/PLA では未処理の CNF/PLA 複合 材料より力学物性は若干向上するものの, B-CNF/PLA 系複 合材料より力学物性改善効果は低減するという結果であっ た。これらの結果は, DMAの結果と同じ傾向を示しており， B-CNF が PLA マトリクス界面を補強する効果は BPFGの反 応置換割合が増加するほど顕著になり, PLAのTg 以上での 力学特性が保持されたものと考えられる。一方, BPAG 修飾 $\mathrm{CNF}$ は BPFG と同じ置換割合で比較すると, 高温での力学 物性向上効果は顕著に発現せず, また $90{ }^{\circ} \mathrm{C}$ の温度環境下で は未処理 CNF 系複合材料とほぼ同程度の力学物性向上効果 であったことより, その CNF と PLA マトリクス界面の補強 効果はカルド系材料より著しく低いものと考えられる.

そこで，各種 CNF とマトリクス間の界面強度を評価する ために, 各 CNF を添加したPLA 複合材料系における $105^{\circ} \mathrm{C}$ での貯蔵弾性率 $\left(E^{\prime}\right)$ の歪み依存性測定を行った結果を Fig. 8 に示す。一般的に, DMA の歪み依存性測定において, フィ ラーの二次凝集体構造の破壊やフィラーとマトリクス間の 剥離等が生じると，ある歪み量以上において $E^{\prime}$ の低下が生 じることが知られている. ${ }^{31}$ 本結果より，BisA-CNF(38.7)/PLA は未処理のCNF/PLA 複合材料より高い $E^{\prime} の$ 值であるものの, 弾性率低下の開始歪みはほぼ同じという結果であった。一 方, PLA 中でのCNF の分散性が良好な B-CNF(38.5)/PLA では, 高い弾性率を有しながら $E^{\prime}$ の低下が生じる歪み量が高歪み 側にシフトする傾向が認められた。この結果は, DMAにお ける高温領域での $E^{\prime}$ の増加, およびや静的引張試験 $\left(90^{\circ} \mathrm{C}\right)$ における力学物性の向上効果が, CNF と PLA 界面の補強効 果に起因するものと考えられる。

Fig. 9 にPLA，未処理のCNFを添加したPLA(CNF/PLA), BisA-CNF(38.7)/PLA，B-CNF(38.5)/PLA 複合材料における熱 機械特性 (TMA) 測定結果を示す。PLA マトリクス単体では,
PLA の $\mathrm{T}_{\mathrm{g}}$ 近傍で線熱膨張係数 (CTE) が大きく増加するのに 対して，いずれの CNF を添加した系においても顕著な増加 現象が認められなかった。これは, CNF 添加 PLA 複合材料 系では, CNFに隣接する PLA 分子は分子運動が拘束され, PLAのガラス転移に伴う体積膨張が抑制されたためと考え られる。本結果は，前述した各種 CNF 添加 PLA 複合材料に おける「 $\tan \delta$ の減少」の結果とも一致するものである。また, B-CNF(38.5)/PLA 複合材料の CTE の值は, Tg 以上の高温領 域において CNF/PLA およびBisA-CNF(38.7)/PLA より小さい という結果になった。これは前述した通りカルド構造を有 する B-CNF が BisA-CNF より PLA マトリクスの改質効果が 高い結果と一致する。

次に, BisA-CNF(38.7)/PLA および B-CNF(38.5)/PLA 複合材 料の TMA カーブより平均線熱膨張係数 (CTE) を算出し, 各 系におけるCTEの実験值と式 (1)より算出した複合モデル に基づく計算值とのフィッティングを行った結果を Fig. 9 中 にあわせて示した，B-CNF およびBisA-CNF 添加 PLA 複合 材料系において，PLAの Tg 近傍におけるフィッティング結 果に差異は認められるものの，ほほ測定した温度範囲にお いて計算式から得られる結果と良い一致を示した。

上記カーブフィッティングより得られた各成分の体積分 率を Table II に示した。本実験に用いた CNF の添加量はい ずれも $1.1 \mathrm{wt} \%$ （体積分率換算で $0.0087 \mathrm{vol} \%$ ） と同じであ り，PLA 成分は $98.9 \mathrm{wt} \%$ （体積分率で $0.9913 \mathrm{vol} \%$ ）である. 各種 CNF と相互作用を有する PLA 成分（PLA'相）に注目 すると，CNF/PLA では約 $0.21 \mathrm{vol} \%$, BisA-CNF(38.7)/PLA で は約 $0.31 \mathrm{vol} \%$ であったが, B-CNF(38.5)/PLA 複合材料では 約 $0.50 \mathrm{vol} \%$ にまで増加するという結果になった。 これは, CNF 表面が B-CNF で改質された結果, PLA との相互作用が 強くなり, 高温領域における力学物性の向上効果, さらに は熱膨張係数の低下効果を引き起こしたものと考えられる. そして，そのPLAの物性改質効果は BPFG で改質した CNF (a) $105^{\circ} \mathrm{C}$

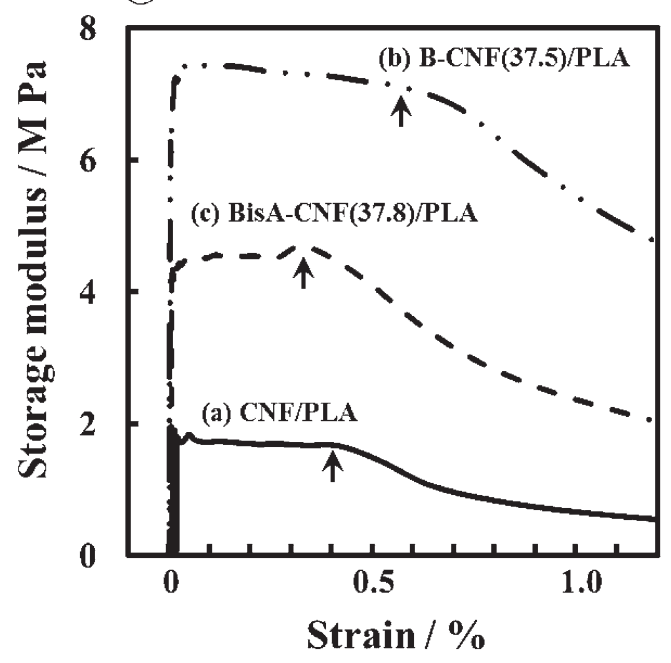

Fig. 8. Variation of storage modulus with strain for several CNF/PLA composites (CNF content $1.1 \mathrm{wt} \%$ ) at $105{ }^{\circ} \mathrm{C}$ : (a) CNF/PLA, (b) B-CNF(38.5)/PLA, and (c) BisA-CNF(38.7)/PLA.

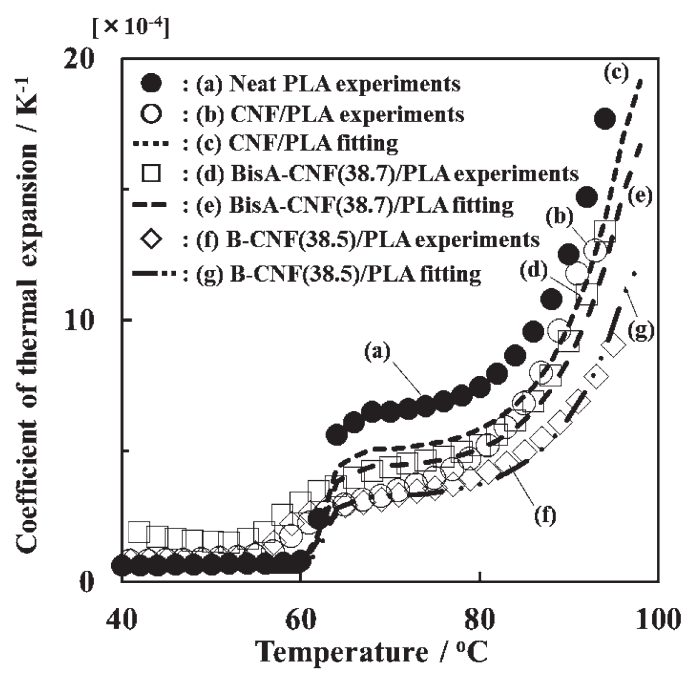

Fig. 9. TMA results and curve fitting results of CTE for neat PLA and several CNF/PLA composites (CNF content $1.1 \mathrm{wt} \%$ ): (a) neat PLA, (b) CNF/PLA, (c) CNF/PLA curve fitting, (d) BisACNF(38.7)/PLA experiments, (e) BisA-CNF(38.7)/PLA curve fitting, (f) B-CNF(38.5)/PLA experiments, and (g) B-CNF(38.5)/ PLA curve fitting. 
で顕著に発現することより, カルド構造という特異的な構 造がこの相互作用に多大な影響を与えていることを示唆す る結果である.

一方, BPFGの表面置換割合が異なる B-CNF(18.4)/PLA, B-CNF(28.5)/PLA, B-CNF(38.5)/PLA 複合材料の熱機械特性 (TMA) 測定結果を Fig.10に示した。本結果において，置換割 合の違いによる熱膨張係数に与える影響は上記未処理 CNF およびBisA-CNF/PLA よりも小さいものの, BPFGの表面置 換割合が高いB-CNFにおいて, 若干の熱膨張係数の低下が 認められる傾向があった。そこで，上記と同様に CTEの実 験值と式 (1)より算出した複合モデルに基づく計算值との フィッティングを行い, 各種 CNF と相互作用を有する PLA 成分 (PLA' 相) を算出した結果を Table II に合わせて示した が, B-CNF(18.4)/PLA では約 0.41 vol\%, B-CNF(28.5)/PLA で は約 0.43, B-CNF(37.5)/PLA では約 0.50 とCTEに与える影 響の差は小さいものの BPFG の表面置換割合が増加するに従 い, CTEは減少する傾向を示した。 以上の結果より, CNF の表面処理は置換する表面処理化合物の構造の違いにより, CNF/PLA 複合材料の熱物性や力学物性に大きな影響を与え ることが分かった、しかしながら，「なぜカルド構造を有す

Table II. Calculated volume fraction of PLA (A), PLA' (A'), and CNF (B) by curve fitting results.

\begin{tabular}{lccc}
\hline Sample code & $\begin{array}{c}\text { PLA phase } \\
(\mathrm{A})\end{array}$ & $\begin{array}{c}\text { PLA' phase } \\
\left(\mathrm{A}^{\prime}\right)\end{array}$ & $\begin{array}{c}\text { CNF phase } \\
(\mathrm{B})\end{array}$ \\
\hline CNF/PLA & 0.781 & 0.2103 & \\
BisA-CNF(38.7)/PLA & 0.678 & 0.3133 & \\
B-CNF(18.4)/PLA & 0.583 & 0.4083 & 0.0087 \\
B-CNF(28.5)/PLA & 0.557 & 0.4343 & \\
B-CNF(37.5)/PLA & 0.492 & 0.4993 & \\
\hline
\end{tabular}

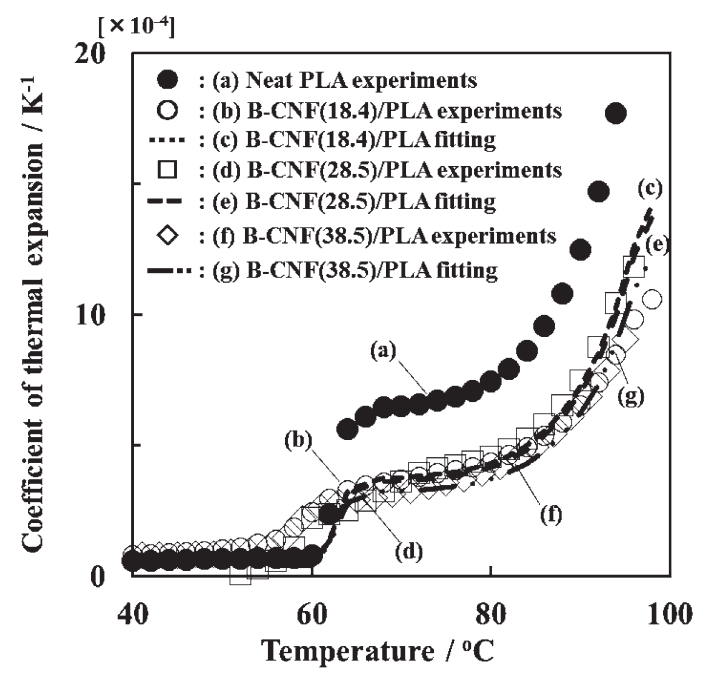

Fig. .10 TMA results and curve fitting results of CTE for neat PLA and several B-CNF/PLA composites (CNF content $1.1 \mathrm{wt} \%$ ): (a) neat PLA, (b) B-CNF(18.4)/PLA experiments, (c) BisA-CNF(18.4)/ PLA curve fitting, (d) B-CNF(28.5)/PLA experiments, (e) B-CNF(28.5)/PLA curve fitting, (f) B-CNF(38.5)/PLA experiments, and (g) B-CNF(38.5)/PLA curve fitting.
る化合物が，なぜそのような顕著な物性改質効果を有する のか？」,さらには「PLA 以外の高分子マトリクスについて も, 同様の効果を発現するのか?」などについては, 現時 点では不明であり, 今後更なる検討が必要である.

\section{4. 結言}

(1) カルド構造を有する BPFG で表面処理を行った CNF(B$\mathrm{CNF}$ ) と PLA の複合化を行った結果, B-CNF は neat CNF と比較して PLA 中での分散性が良好であることが分かっ た。また，BPFGの反応置換割合の増加とともにPLAの ガラス転移温度 $(\mathrm{Tg})$ 以上の領域における貯蔵弾性率 $E^{\prime}$

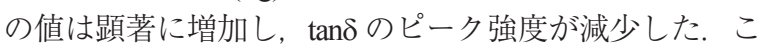
れは, PLA との界面近傍に存在する CNF 或いは B-CNF がPLAの分子運動を抑制したためと考えられる。

(2) 一方，カルド構造を含まない BisA 型構造を有する BPAG で表面処理したBisA-CNFを添加したPLA 複合 材料 (BisA-CNF(38.7)/PLA) においては, ガラス転移温 度 $(\mathrm{Tg})$ 以上の領域において貯蔵弾性率 $E^{\prime}$ の増加と $\tan \delta$ のピーク強度の減少を確認したものの, その物性改質 効果の影響はB-CNF(38.5)/PLA より限定的であった。 これは, “カルド構造”という剛直で自由体積空間が広 いという特徴がその一要因として考えられるものの, 不明な点も多く今後さらなる検討が必要である.

(3) 各種 CNF/PLA 複合材料の貯蔵弾性率 $E^{\prime}$ の歪み依存 性測定より，B-CNF(38.5)/PLA では高い $E^{\prime}$ を維持した 状態が高歪み側まで継続することが分かった。 また, BisA-CNF(38.7)/PLA では未処理の CNF 添加 PLA と比 べて， $E^{\prime}$ の值は高いもののそれを維持する歪み量は未 処置 CNF 複合材料系と同程度であった。本結果より, B-CNF 添加系では，CNF と PLA との界面補強効果がよ り強固に行われており, 当該界面での剥離が抑制され ていることが示唆された。

(4) CNF/PLA，BisA-CNF(38.7)/PLA，およびB-CNF(38.5)/ PLA 複合材料の TMA 測定において，B-CNF/PLA が Tg 以上の温度範囲において CNF/PLA，BisA-CNF/PLA よ りも小さい熱澎張係数を有することが分かった。 これ は, BPFGで表面処理したCNFでは，PLAとの界面補 強効果がより強固なったためであると考えられる。ま た, 複合則より求められる線熱膨張係数の算出式 (1) と 実験值を比較することにより，PLA 複合材料中におけ る各相の割合を算出した結果, CNF と相互作用してい る PLA 相 (PLA'相) は B-CNF/PLA(MA) 複合材料で最 も多くなり，その次にBisA-CNF/PLA, CNF/PLA の順 に小さくなることが分かった。本結果は, PLA 中での CNF の分散性および PLA の Tg 以上の温度域における $E^{\prime}$, および $\tan \delta$ の゚゚ーク強度の順番と一致する結果で あり, BPFG で表面処理した CNF が効果的にPLAの力 学物性, 熱物性を改質したものと考えられる.

(5)次に, BPFGの表面置換割合の異なる B-CNF/PLA の 熱膨張係数に与える影響を検討した結果，置換割合の 違いの効果は小さいながらも BPFGの表面置換割合が 高い B-CNF/PLA の方が CNF と相互作用している PLA 相（PLA'相）の割合が増加することが分かった。

以上の結果より，カルド材料で表面処理を行った CNF は 
PLA マトリクス中で効果的に分散すると共にPLA 相と強 い相互作用を有し, PLAの $\mathrm{Tg}$ 以上の温度域における $E^{\prime} の$ 值の増加および PLA マトリクス界面との補強効果, 更には PLA 分子の分子運動性の抑制効果を顕著に発現することが 分かった，今後は，「なぜカルド材料が PLA とこのような特 殊な相互作用を有するのか? について, 分子動力学等の 計算を用いた検討を行う必要がある。

\section{謝辞}

TEM 観察にご協力いただきました（株）東レリサーチセ ンター 形態科学研究部 形態科学第 2 研究室 増田昭博博士に 厚く御礼申し上げます。

\section{REFERENCES}

1) Li H, Huneault MA, Polymer, 48, 6855 (2007).

2) Okamoto M, Shinoda Y, Kinami N, Okuyakma T, $J$ Appl Polym Sci, 57, 1055 (1995).

3) Kolstad JJ, J Appl Polym Sci, 62, 1079-1091 (1996).

4) Ikeda Y, Jamshisi K, Tsuji H, Hyon S-H, Macromolecules, 20, 906 (1987).

5) Bhardwaj R, Mohanty AK, Biomacromolecules, 8, 2476 (2007).

6) Yamada Y, Ueda K, Ray SS, Okamoto M, Kobunshi Ronbunshu, 59, 760 (2002).

7) Abe K, Yano H, Cellulose, 6, 1017 (2009).

8) Alemdar A, Sain M, Bioresour Technol, 99, 1664 (2008).

9) Dufresne A, Vignon MR, Macromolecules, 31, 2693 (1998).

10) Bhattacharya D, Germinario IT, Winter WT, Carbohydr Polym, 73, 371 (2008).

11) Zuluaga R, Putaux JL, Restrepo A, Cellulose, 14, 585 (2007).

12) Bhatnagar A, Sain M, J Reinf Plast Comp, 24, 1259 (2005).

13) Nishino T, Takano K, Makamae KJ, Polym, Sci Part B, Polm Phys, 33, 1647 (1995).
14) Helbert W, Cavaille JY, Dufresne A, Polm, Comp, 17, 604 (1996).

15) Page DH, El-Hosseiny F, J Pulp and Paper Sci, 9, 99 (1983).

16) Sugiyama J, Vuong R, Chanzy H, Macromolecules, 24, 4168 (1991).

17) Nishino T, Matsuda I, Hirano K, Macromolecules, 37, 7683 (2004).

18) Nakagaito AN, Yano H, Appl Phys A-Material Science and Processing, 80, 155 (2005).

19) Cheng Q, Wang S, Rials TG, Lee SH, Cellulose, 14, 593 (2007).

20) Jonoobi M, Harun J, Mathew AP, Oksman K, Comp Sci Technol, 70, 1742 (2010).

21) Iwatake A, Nogi M, Yano H, Comp Sci Technol, 68, 2103 (2008).

22) Boldizar A, Klason C, Kubat J, Naslund P, Saha P, Inter J Polym Mater, 11, 229 (1987).

23) Iwamoto S, Nakagaito AN, Yano H, Appl Phys A, 89, 461 (2007).

24) Isogai $\mathrm{A}$, Kato $\mathrm{Y}$, Cellulose, 4, 153 (1998).

25) Semba T, Ito A, Kitagawa K, Nakatani T, Yano H, Sato A, $J$ Appl Polym Sci, 131 (2014).

26) Hayashi N, Ishihara M, Sugiyama J, Okano T, Carbohydr Res, 305, 109 (1997).

27) Kawasaki S, Yamada M, Kobori K, Fengzhe J, Takata T, $J$ Appl Polym Sci, 118, 2690 (2010).

28) Tokumitsu K, Matsuura T, Kawasaki S, Tashiro K, J Mater Sci, Japan, 64, 1 (2015).

29) Terakura K, Tokumitsu K, Yamada M, Sugimoto M, Nihon Reoroji Gakkaishi, 44, 39 (2016).

30) Turner PS, J Res NBS, 37, 239 (1946).

31) Manna AK, De PP, Tripathy DK, De SK, J Appl Polym Sci, 70, 723 (1998). 